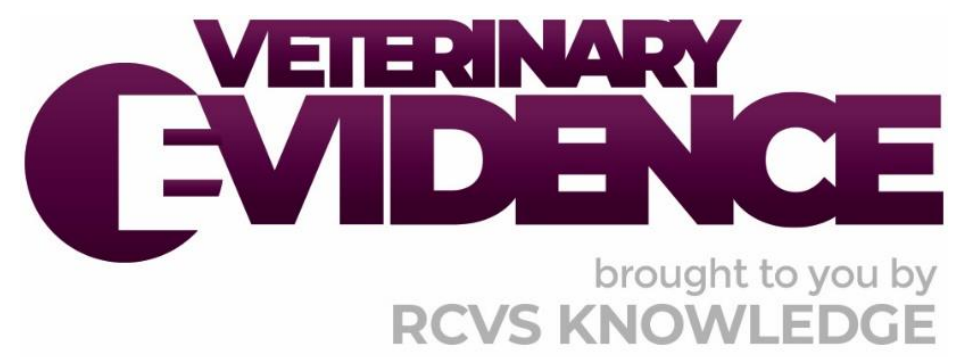

\title{
In newborn piglets does drying versus no intervention reduce the risk of mortality pre-weaning?
}

\section{A Knowledge Summary by}

Nicola Blackie BSc (Hons) $\mathrm{PhD}^{1}$

\footnotetext{
${ }^{1}$ Department of Pathobiology and Population Sciences, Royal Veterinary College, Hatfield, AL9 7TA

* Corresponding Author (nblackie@rvc.ac.uk)
}

ISSN: 2396-9776

Published: 12 Nov 2019

in: Vol 4, Issue 4

DOI: $10.18849 /$ VE.V4I4.245

Reviewed by: John Carr (BVSc, PhD, DPM, DiplECPHM, MRCVS. - Specialised Pig Vet), Vengai Mavangira (BVSC, DACVIM) and Duncan Berkshire (MA VetMB MSc CertPM MRCVS) 


\title{
KNOWLEDGE SUMMARY
}

\author{
PICO question \\ In newborn piglets, does drying piglets, compared to no intervention, reduce the level of mortality pre-weaning \\ (up to 28 days)? \\ Clinical bottom line \\ Data specifically evaluating drying piglets are limited. Many papers had multiple factors evaluated or were \\ assessments of management in general. There is evidence that drying piglets can reduce mortality and improve \\ thermoregulation of piglets. The cost of such interventions has not been appraised and should be considered on \\ a case-by-case basis. Therefore, currently when advising farmers it could be suggested that the drying of piglets \\ may form part of a number of recommendations given to reduce piglet mortality pre-weaning.
}

\section{Clinical Scenario}

Piglets are born with limited energy reserves and are not licked dry by the sow therefore risk hypothermia around the time of birth. Mortality levels pre-weaning on indoor pig farms in the UK average $11.6 \%$ (AHDB, 2019). The practice of drying piglets is more common in the US than in the UK based on anecdotal evidence. Conversations with UK pig farmers and veterinarians revealed that there are mixed strategies for managing the newborn piglet indoors, many of which do not include a direct intervention to dry the piglet. Indirect methods of drying piglets may include lamps at the rear end of the sow or providing bedding. Drying piglets may be a way of reducing the risk of hypothermia and thus reduce the risk of mortality. Therefore, an appraisal of the evidence could be used to advise farmers on best practice.

\section{Clinical Scenario}

There are three methods of drying piglets from the literature. One is drying with stimulation such as using paper towels, cloth towels or straw, as well as drying the piglets they may also receive stimulation from the act of rubbing them. Another method included the use of drying powders and the third method was moving the piglet under a lamp. From the evidence it is clear that drying piglets can result in lower mortality however, a simpler method may be to place the piglet under a heat lamp (Andersen et al., 2009). Drying piglets with stimulation without combination of other strategies was only assessed in four studies (Christison et al., 1997; McGinnis et al., 1981; Pan, 1995; and Vasdal et al., 2011), of which one study did not record mortality (Pan, 1995), one study showed no effects on mortality and two showed an improvement in mortality where piglets were dried (Christison et al., 1997; and Vasdal et al., 2011). A further two studies included drying as part of an "advanced care" around farrowing which included a number of interventions (Dewey et al., 2008; and White et al., 1996). Dewey et al. (2008) found no impact of extra care on mortality however, they did have low mortality levels in the study overall (7-8 \%). In contrast, White et al. (1996) had less mortality when farrowing was assisted and piglets were dried among other interventions.

When comparing with the average level of mortality on UK pig farms $11.6 \%$ (AHDB, 2019); mortality was considerably higher where no intervention was made in one study of $21 \%$ (Christison et al., 1997) and 
similar in two studies (Andersen et al., 2009; Vasdal et al., 2011).

\section{Summary of the evidence}

\begin{tabular}{|c|c|}
\hline \multicolumn{2}{|l|}{ Andersen et al. (2009) } \\
\hline Population: & $\begin{array}{l}\text { Litters from } 67 \text { (Landrace } X \text { Yorkshire) healthy sows; parity } 2-4 \\
\text { Housed in loose farrowing pens ( } 3.2 \mathrm{~m} \times 2.0 \mathrm{~m} \text { ) with solid, concrete } \\
\text { floor in the front two thirds of the pen with the rest slatted } \\
\text { Room temperature } 18-20^{\circ} \mathrm{C} \\
\text { Natural farrowing }\end{array}$ \\
\hline Sample size: & 67 litters (total number of live born piglets not given) \\
\hline Intervention details: & $\begin{array}{l}\text { Three treatment groups: } \\
\text { - Control }(\mathrm{C}) \mathrm{n}=23 \text { litters, no supervision of farrowing, farmer } \\
\text { could help with difficult births but not to intervene if he/she } \\
\text { heard a piglet being crushed } \\
\text { - Heat Lamp }(\mathrm{HL}) \mathrm{n}=22 \text { litters, piglets placed under heat lamp } \\
\text { directly after birth (lamp in the creep area) } \\
\text { - Dried and Heat Lamp (DHL) } n=22 \text { litters, piglets were dried } \\
\text { with straw and paper towel, then placed under heat lamp } \\
\text { directly after birth (lamp in the creep area) }\end{array}$ \\
\hline Study design: & Non-randomised controlled trial \\
\hline Outcome studied: & $\begin{array}{l}\text { - Mortality } \\
\text { - Reason for death (via post mortem examination) }\end{array}$ \\
\hline $\begin{array}{l}\text { Main findings: } \\
\text { (relevant to PICO question): }\end{array}$ & $\begin{array}{l}\text { - Mortality of live born piglets was lower in } \mathrm{HL}(7.6 \%) \text { and } \mathrm{DHL} \\
\text { (6.7\%) interventions when compared to control (11.7\%). No } \\
\text { significant difference between } \mathrm{HL} \text { and } \mathrm{DHL} \\
\text { - Proportion of starved piglets was significantly lower in the } \\
\text { HL treatment than in the } \mathrm{DHL} \text { and control group } \\
\text { - DHL group had the lowest number of piglets crushed } \\
\text { (13.8\%). HL less crushed than control (34.8\% and } 47.9 \% \text {, } \\
\text { respectively) } \\
\text { Paper only gives percentage data. }\end{array}$ \\
\hline Limitations: & $\begin{array}{l}\text { - It is not clear if the treatments for each group were carried } \\
\text { out in the same room as each other or in different rooms- } \\
\text { the room environment could influence the results } \\
\text { - Raw data hard to extrapolate from graphs } \\
\text { - There was no drying only treatment }\end{array}$ \\
\hline
\end{tabular}

Christison et al. (1997)

Population: Litters from 11 sows (cross-bred); parity not given

Housed in farrowing crates (Conventional $0.45 \mathrm{~m} \times 2.1-\mathrm{m}$ farrowing

crates with raised perforated floors)

Room temperature not given 


\begin{tabular}{|c|c|}
\hline & $\begin{array}{l}\text { Induced farrowing } \\
\text { Trial conducted from } 0-21 \text { days of age (weaning age not given) }\end{array}$ \\
\hline Sample size: & $\begin{array}{l}98 \text { piglets (litters standardised to nine piglets/sow - additional } \\
\text { piglets were fostered off) }\end{array}$ \\
\hline Intervention details: & $\begin{array}{l}\text { Three treatment groups - the three treatments were randomly } \\
\text { assigned within birth order trios (first three born, second } \\
\text { three born, final three born were trio 1-3, respectively): } \\
\text { - Control } n=33 \text { piglets - Piglets were not handled except to } \\
\text { dry and colour one ear (method of drying not specified) } \\
\text { - Dried } n=32 \text { piglets - Piglets dried at birth with paper towel } \\
\text { and returned to where they were born, marked on back } \\
\text { - Heat Lamp } n=33 \text { piglets - Piglets picked up by back legs and } \\
\text { moved under heat lamp, one ear was dried and coloured for } \\
\text { identification (method of drying ear not specified) } \\
\text { Mucus was cleared from the nose and mouth for all groups. } \\
\text { Umbilical cords were detached or shortened if required to ensure } \\
\text { that it did not hinder their movement. }\end{array}$ \\
\hline Study design: & Randomised controlled trial \\
\hline Outcome studied: & $\begin{array}{l}\text { - Teat seeking success (made up of latency to udder contact } \\
\text { and first suckle) } \\
\text { - Weights at various time points ( } 2 \text { hours, } 6 \text { hours, days } 1,3,7 \text {, } \\
14 \text { and } 21 \\
\text { - Mortality }\end{array}$ \\
\hline $\begin{array}{l}\text { Main findings: } \\
\text { (relevant to PICO question): }\end{array}$ & $\begin{array}{l}\text { - No effect of any treatment on mean time to udder contact } \\
\text { - No effect of any treatment on mean time to suckle } \\
\text { - No effect of any treatment on weight at } 2 \text { hours or average } \\
\text { daily gain at } 24 \text { hours and } 21 \text { days } \\
\text { - Mortality higher in control piglets } 7 / 33(21 \%) \text { compared to } \\
\text { dried piglets } 2 / 33(6 \%) \text { and heat lamp piglets } 0 \% \text { mortality }\end{array}$ \\
\hline Limitations: & $\begin{array}{l}\text { - Litters reduced to nine piglets which may mean that the } \\
\text { litters were smaller than normal which may be less } \\
\text { representative of the population as the piglets had less } \\
\text { competition for teat access } \\
\text { - Induced farrowing (this can make piglets less viable } \\
\text { however, equal across treatments) } \\
\text { - Marking process may confound results - dried piglets } \\
\text { perhaps should have been marked on ear as well } \\
\text { Relatively small sample size }\end{array}$ \\
\hline
\end{tabular}

Dewey et al. (2008)

Population: Litters from 126 sows (breed not given); parity 2-7+, mean 5.7

Housed in farrowing crate - details not given

Natural farrowing

Room temperature not given 


\begin{tabular}{|c|c|}
\hline & Weaning age ranged from $16-28$ days with an average of 20.2 days \\
\hline Sample size: & 1367 piglets \\
\hline Intervention details: & $\begin{array}{l}\text { Two treatment groups: } \\
\text { - Standard Care Litters } n=60 \text { litters - Cross-fostering at } 24 \mathrm{~h} \text {, } \\
\text { day } 1 \text { processing = teeth clipping, tail docking, and iron } \\
\text { injection. Instrument's not cleaned between pigs, castrated } \\
\text { at } 10 \text { days and given further iron injection } \\
\text { - Maximal Care litters } n=66 \text { litters - As standard care with } \\
\text { instruments dipped in antiseptic between uses and } \\
\text { castration wound treated with iodine. Piglets dried (method } \\
\text { not stated) and assisted at farrowing, split suckling } \\
\text { undertaken, electrolytes given and chilled piglets received } \\
\text { extra care. Sows given extra meal }\end{array}$ \\
\hline Study design: & Randomised controlled trial \\
\hline Outcome studied: & $\begin{array}{l}\text { - Weight at } 16 \text { days } \\
\text { - } \text { Mortality } \\
\text { - } \text { Morbidity }\end{array}$ \\
\hline $\begin{array}{l}\text { Main findings: } \\
\text { (relevant to PICO question): }\end{array}$ & $\begin{array}{l}\text { - No effect of treatment on mortality (standard }=8.3 \% \text { and } \\
\text { maximal }=7.2 \% \text { ) } \\
\text { - Maximal pigs heavier at } 16 \text { days of age } \\
\text { Only percentage data available }\end{array}$ \\
\hline Limitations: & $\begin{array}{l}\text { - Lot of variables changed between treatments, cannot } \\
\text { decipher if one or more additional care factor influenced } \\
\text { outcomes more than another } \\
\text { - System comparison rather than treatment/control study } \\
\text { - Drying of piglets was not an independent treatment }\end{array}$ \\
\hline
\end{tabular}

\begin{tabular}{|c|c|}
\hline \\
\hline \multicolumn{2}{|c|}{$\begin{array}{l}\text { McGinnis et al. (1981) } \\
\qquad \begin{array}{l|l}\text { Population: } & \text { Litters from } 33 \text { sows (breed and parity not given) } \\
\text { Housing - farrowing crate concrete floor } \\
\text { Natural farrowing } \\
\text { Room temperature } 22^{\circ} \mathrm{C} \\
& \text { Trial conducted from } 0 \text { to } 5 \text { days of age }\end{array}\end{array}$} \\
\hline Sample size: & \multirow[b]{2}{*}{$\begin{array}{l}326 \text { piglets from } 33 \text { sows } \\
2 \times 2 \times 2 \text { Factorial Design } 326 \text { piglets were divided over eight treatment } \\
\text { groups (exact number undergoing each treatment was not } \\
\text { specified): } \\
\text { - Alternate piglets of each sex were dried with paper towel } \\
\text { within } 2 \text { minutes of birth } \\
\text { - Two different floor temperatures } 20^{\circ} \mathrm{C} \text { and } 30^{\circ} \mathrm{C} \\
\text { - Supplemental heat via } 250 \text {-watt infrared heat lamp versus } \\
\text { light bulb }\end{array}$} \\
\hline Intervention details: & \\
\hline Study design: & Randomised controlled trial \\
\hline
\end{tabular}




\begin{tabular}{|c|c|}
\hline Outcome studied: & $\begin{array}{l}\text { - Skin temperature measured at } 30 \text { minutes, } 1 \text { hour then } \\
\text { hourly to } 8 \text { hours after birth using an infrared thermometer } \\
\text { - Rectal temperature was taken hourly to } 8 \text { hour then at } 1,2 \\
\text { and } 5 \text { days of age } \\
\text { - Body weight measured at birth, } 1,2 \text { and } 5 \text { days of age } \\
\text { - Blood samples at birth, } 2 \text { and } 5 \text { days of age } \\
\text { - Survival rates to } 5 \text { days }\end{array}$ \\
\hline $\begin{array}{l}\text { Main findings: } \\
\text { (relevant to PICO question): }\end{array}$ & $\begin{array}{l}\text { Exact numbers of piglets in each treatment group were not specified } \\
\text { - Piglets dried at birth had higher rectal temperatures at } 1 \\
\text { hour post birth }\left(37.9^{\circ} \mathrm{C}\right) \text { compared to non-dried piglets } \\
\left(37.4^{\circ} \mathrm{C}\right) \text { all other time points were similar between dried } \\
\text { and non-dried piglets } \\
\text { - Supplemental heat treatments had higher skin temperatures } \\
\text { from } 5-8 \text { hours after birth } \\
\text { - Dried piglets had higher skin temperatures at } 30 \text { minutes } \\
\left(34.2^{\circ} \mathrm{C}\right) \text { after birth compared with non-dried piglets }\left(33.0^{\circ} \mathrm{C}\right) \\
\text { - Dried piglets had higher skin temperatures at } 1 \text { hour after } \\
\text { birth }\left(34.9^{\circ} \mathrm{C}\right) \text { compared with non-dried piglets }\left(34.5^{\circ} \mathrm{C}\right) \text {. } \\
\text { - No impact of drying piglets on cortisol levels }\end{array}$ \\
\hline Limitations: & $\begin{array}{l}\text { - Since this paper was published genetics have changed } \\
\text { dramatically which may influence comparison with other } \\
\text { studies } \\
\text { - Average } 9.8 \text { piglets per litter so no issues with large litter } \\
\text { and subsequent competition for teats } \\
\text { - Exact number of piglets in each treatment group not } \\
\text { specified }\end{array}$ \\
\hline
\end{tabular}

Pasca et al. (2008)

\begin{tabular}{|c|c|}
\hline Population: & $\begin{array}{l}\text { Litters from } 12 \text { sows (Landrace and Large White); parity } 1(n=6) \text { and } \\
\text { parity } 3(n=6) \\
\text { Housing - no details given } \\
\text { No details of natural or induced farrowing } \\
\text { Room temperature not given } \\
\text { Study conducted up to weaning - weaning age not given }\end{array}$ \\
\hline Sample size: & 143 piglets from 12 sows \\
\hline Intervention details: & $\begin{array}{l}\text { Three treatment groups; two parity } 1 \text { and two parity } 3 \text { sows in each: } \\
\text { - Control } n=53 \text { piglets }- \text { no intervention } \\
\text { - Mistral powder } n=45 \text { piglets }- \text { powder applied to skin } \\
\text { - Mistral powder }+ \text { injection } n=45 \text { piglets }- \text { powder applied to } \\
\text { skin and injection of Dexamethasone (intramuscular } 0.1 \\
\mathrm{mg} / \text { piglet) }\end{array}$ \\
\hline Study design: & Randomised controlled trial \\
\hline Outcome studied: & $\begin{array}{l}\text { - Rectal temperature }(1,3,6,12 \text { and } 48 \mathrm{~h} \text { after birth) } \\
\text { - } \quad \text { Blood glucose levels }(1,12 \text { and } 24 \mathrm{~h} \text { after birth) }\end{array}$ \\
\hline
\end{tabular}




\begin{tabular}{|c|c|}
\hline & - Birth and weaning weights \\
\hline $\begin{array}{l}\text { Main findings: } \\
\text { (relevant to PICO question): }\end{array}$ & $\begin{array}{l}\text { - Results stated that the body surface was dry in } 10-15,1-2 \\
\text { and } 1-2 \text { minutes post parturition for control, Mistral powder } \\
\text { and Mistral powder + injection, respectively. However, no } \\
\text { definition given as to how the surface of the piglet being dry } \\
\text { is defined from the data presented } \\
\text { - Differences in temperature profiles: control piglets saw a } \\
\text { decrease of } 1.1 \text { to } 1.8^{\circ} \mathrm{C} \text { in the first hour following birth. } \\
\text { Piglets treated with Mistral powder had a decrease of } 0.5 \text { to } \\
0.8^{\circ} \mathrm{C} \text { in the first hour following birth. Piglets treated with } \\
\text { Mistral powder }+ \text { injection had a decrease of } 0.5 \text { to } 1.8^{\circ} \mathrm{C} \text {. } \\
\text { The glycaemia at } 1 \text { hour after parturition records the highest } \\
\text { values in the piglets treated with Mistral powder (58-61 } \\
\text { mg/ml) and Mistral powder + injection, compared to control } \\
\text { group (56-57 mg/ml) } \\
\text { Birth weights were } 1.55 \mathrm{~kg}, 1.61 \mathrm{~kg} \text { and } 1.53 \mathrm{~kg} \text { for control, } \\
\text { Mistral powder and Mistral powder }+ \text { injection respectively. } \\
\text { Weaning weights were } 8.47 \mathrm{~kg}, 8.77 \mathrm{~kg} \text { and } 8.80 \mathrm{~kg} \text { for } \\
\text { control, Mistral powder and Mistral powder + injection } \\
\text { respectively these data are all calculated by the author of } \\
\text { this Knowledge Summary, from raw data given in the paper } \\
\text { Mortality was not discussed in the paper however, from the } \\
\text { raw data the author of this Knowledge Summary calculated } \\
\text { mortality as } 5 / 53 \text { (9.4\%), } 1 / 45 \text { ( } 2.2 \% \text { ) and } 2 / 45 \text { (4.4\%) for } \\
\text { control, Mistral powder and Mistral powder + injection } \\
\text { respectively, assuming that piglets with no weaning data } \\
\text { died }\end{array}$ \\
\hline Limitations: & $\begin{array}{l}\text { - Methods lack description of what "Mistral" powder is, on } \\
\text { investigation it is actually a blend of desiccants (mineral), } \\
\text { seaweed, clay and essential oils which the piglets are dipped } \\
\text { into. More information on Dexamethasome required as well } \\
\text { - Not clear what statistical analysis was undertaken (if any) } \\
\text { tables of raw data presented and discussed } \\
\text { - Mortality not measured however, within the discussion } \\
\text { dried piglets were stated to be heavier at weaning which } \\
\text { may improve survival. This was calculated by the author of } \\
\text { this Knowledge Summary using the assumption that piglets } \\
\text { with no weaning weight recorded had died } \\
\text { - No statistical tests or variation of data stated, just numbers } \\
\text { written in the text and tables of raw data presented }\end{array}$ \\
\hline
\end{tabular}

Pan (1995)

Population: Large White $\mathrm{x}$ Yorkshire Piglets, sow numbers; parity not given Housed in individual farrowing pen with concrete floor (dimensions not given) - no bedding

Temperature $23-35^{\circ} \mathrm{C}$

Natural farrowing 


\begin{tabular}{|c|c|}
\hline & Study conducted for 9 days post-farrowing (weaning age not stated) \\
\hline Sample size: & 44 piglets \\
\hline Intervention details: & $\begin{array}{l}\text { Two treatment groups: } \\
\begin{array}{l}\text { - } \\
\text { Control - no intervention piglets allowed to dry naturally } \\
(n=22) \\
\text { - } \\
\text { Dried - piglets dried immediately after birth with a clean dry } \\
\text { cloth }(n 22)\end{array}\end{array}$ \\
\hline Study design: & Randomised controlled trial \\
\hline Outcome studied: & $\begin{array}{l}\text { - Rectal temperature taken at } 0.5,14,26,38 \text { and } 50 \text { hours } \\
\text { post birth and days } 3-9 \text { post birth } \\
\text { - Skin temperature taken at } 0.5,14,26,38 \text { and } 50 \text { hours post } \\
\text { birth and days 3-9 post birth }\end{array}$ \\
\hline $\begin{array}{r}\text { Main findings: } \\
\text { (relevant to PICO question): }\end{array}$ & $\begin{array}{l}\text { - No treatment effects seen on skin or rectal temperatures at } \\
\text { any time point with the exception of } 26 \text { hours after birth. At } \\
26 \text { hours post birth rectal temperature was } 103.37^{\circ} \mathrm{F} \text { for } \\
\text { dried piglets compared with } 103.23^{\circ} \mathrm{F} \text { for non-dried piglets. } \\
\text { At } 26 \text { hours post birth skin temperature was } 103.83^{\circ} \mathrm{F} \text { for } \\
\text { dried piglets compared with } 103.79^{\circ} \mathrm{F} \text { for non-dried piglets }\end{array}$ \\
\hline Limitations: & $\begin{array}{l}\text { - Small sample size } \\
\text { - Limited detail on the sows used } \\
\text { - } \text { Quite warm ambient temperature }\left(35^{\circ} \mathrm{C}\right) \text { during experiment } \\
\text { which may explain lack of difference between the groups } \\
\text { - Mortality and growth rates not measured }\end{array}$ \\
\hline
\end{tabular}

\begin{tabular}{|c|c|}
\hline \multicolumn{2}{|l|}{ Vasdal et al. (2011) } \\
\hline Population: & $\begin{array}{l}\text { Litters from } 67 \text { (Yorkshire X Norwegian Landrace) sows; parity 1-7 } \\
\text { (average } 2.7 \pm 0.2 \text { ) } \\
\left.\text { Housed in individual farrowing pens (Tunby }{ }^{\circledast}\right) 6.2 \mathrm{~m}^{2} \text { in total. Sow } \\
\text { area }=5.0 \mathrm{~m}^{2} \text { with } 2.7 \mathrm{~m}^{2} \text { slatted plastic floor. Sawdust on floor } \\
\text { during farrowing } \\
\text { Farrowing room temperature } 20^{\circ} \mathrm{C} \text { on day of farrowing, reduced to } \\
16^{\circ} \mathrm{C} \text { from next day } \\
\text { Natural farrowing } \\
\text { Weaning age not given }\end{array}$ \\
\hline Sample size: & 872 piglets \\
\hline Intervention details: & $\begin{array}{l}\text { Six treatment groups (all piglets had rectal temperature taken and } \\
\text { birth order marked after which they were treated according to one } \\
\text { of the following): } \\
\text { - Control ( } n=14 \text { litters) - piglet placed back at birth location } \\
\text { - Creep ( } n=13 \text { litters) - Piglet placed in the creep area } \\
\text { - Udder ( } n=10 \text { litters) - piglet placed at udder } \\
\text { - Dry ( } n=10 \text { litters) - Piglet was dried with straw and paper } \\
\text { - towel for } 15 \text { seconds and placed back where it was found } \\
\text { - Dry/Creep ( } n=9 \text { litters) - Piglet was dried with straw and } \\
\text { paper towel for } 15 \text { seconds and placed in the creep area }\end{array}$ \\
\hline
\end{tabular}




\begin{tabular}{|c|c|}
\hline & $\begin{array}{l}\text { - Dry/Udder ( } \mathrm{n}=11 \text { litters) - Piglet was dried with straw and } \\
\text { paper towel for } 15 \text { seconds and placed at udder }\end{array}$ \\
\hline Study design: & Randomised controlled trial \\
\hline Outcome studied: & $\begin{array}{ll}\text { - } & \text { Weight (birth, } 2 \mathrm{~h}, 24 \mathrm{~h}) \\
\text { - } & \text { Time of birth } \\
\text { - } & \text { Latency to suckle } \\
\text { - } & \text { Rectal temperature (birth, 2h, 24h) } \\
\text { - } & \text { Mortality }\end{array}$ \\
\hline $\begin{array}{l}\text { Main findings: } \\
\text { (relevant to PICO question): }\end{array}$ & $\begin{array}{l}\text { - Significantly more piglets died in the Udder treatment (i.e. } \\
\text { not dried), no other treatment effects on mortality. } \\
\text { - Mortality was: } \\
- \text { Control } 7.9 \% \\
-\quad \text { Creep } 11.5 \% \\
-\quad \text { Udder } 15.1 \% \\
-\quad \text { Dry } 9.7 \% \\
-\quad \text { Dry/Creep } 7.1 \% \\
-\quad \text { Dry/Udder } 9.3 \% \\
\text { - Drying and placing piglets at the udder reduced mortality in } \\
\text { one batch but not in the other two } \\
\text { Piglets placed near the udder were faster to suckle } \\
\text { Only percentage data available }\end{array}$ \\
\hline Limitations: & $\begin{array}{l}\text { - Number of litters not equal across the treatment groups. } \\
\text { - The method of randomisation is not specified }\end{array}$ \\
\hline
\end{tabular}

White et al. (1996)

\begin{tabular}{|c|c|}
\hline Population: & $\begin{array}{l}\text { Litters from } 60 \text { (York X Landrace) sows; parity 1-13 } \\
\text { Housed in diagonal farrowing crates } 2.0 \mathrm{~m} \times 0.76 \mathrm{~m} \\
\text { Farrowing room temperature } 22^{\circ} \mathrm{C} \\
\text { Natural farrowing } \\
\text { Study conducted up to } 21 \text { days post farrowing (assumed weaning } \\
\text { age) }\end{array}$ \\
\hline Sample size: & 626 piglets \\
\hline Intervention details: & $\begin{array}{l}\text { Two treatment groups: } \\
\text { - Control ( } n=308) \text { - no intervention } \\
\text { - Treatment (Attended) }(n=318) \text { - automated alert of } \\
\text { farrowing followed by attendance by stockperson undertook } \\
\text { the following procedures. Piglets were dried, umbilicus tied, } \\
\text { oral and nasal cavities suctioned, oxygen supplied, bovine } \\
\text { colostrum administered and placed on teat }\end{array}$ \\
\hline Study design: & Randomised controlled trial \\
\hline Outcome studied: & $\begin{array}{ll}\text { - } & \text { Mortality } \\
\text { - } & \text { Cause of mortality } \\
\text { - } & \text { Weight (birth, days } 7,14,21 \text { ) }\end{array}$ \\
\hline
\end{tabular}




\begin{tabular}{|c|c|}
\hline & - Haematocrit (birth, days $7,14,21$ ) \\
\hline $\begin{array}{l}\text { Main findings: } \\
\text { (relevant to PICO question): }\end{array}$ & $\begin{array}{l}\text { - Overall mortality significantly lower in attended farrowing } \\
32 / 318(10.1 \%) \text { compared with control } 56 / 308 \text { (18.2\%) these } \\
\text { data include stillbirths. Excluding stillbirths mortality was } \\
27 / 318(8.5 \%) \text { and } 38 / 308 \text { ( } 12.3 \%) \text { for attended and } \\
\text { unattended farrowing respectively. } \\
\text { - Significantly more piglets were stillborn, starved and } \\
\text { contracted e-coli in the control group } \\
\text { - Weight of control piglets higher at birth (assumed that they } \\
\text { had suckled before weighing) } \\
\text { Mean weight at } 21 \text { days higher for the attended piglets ( } 5.33 \\
\mathrm{~kg} \text { ) versus (5.09 } \mathrm{kg} \text { ) }\end{array}$ \\
\hline Limitations: & $\begin{array}{l}\text { - No drying only group, drying formed part of a number of } \\
\text { interventions made at birth } \\
\text { - Large range of parities however, similar between treatment } \\
\text { groups }\end{array}$ \\
\hline
\end{tabular}

\section{Appraisal, application and reflection}

When appraising the evidence on this topic it became clear that there are limited papers which can be used to address this research question. A number had to be excluded due to not being published in English ( $n=6)$ and a large number were not directly related to the PICO question as they addressed general management practices; sow management or older piglets. A number were also related to embryo production and development. Papers which were not published in English could not be translated for this knowledge summary. We excluded them from the appraisal as only the abstract was available.

Where sows are loose housed, drying and placing piglets under a heat lamp did reduce death from crushing (Andersen et al., 2009), overall however, mortality was similar whether piglets were dried and placed under a lamp or just placed under a lamp in comparison to a control. Within this experiment there was no drying only treatment (Andersen et al., 2009). Whereas Christison et al. (1997) compared no intervention or control with drying piglets and moving piglets under a heat lamp without drying them. This was a smaller cohort of piglets than that of (Andersen et al., 2009) and the litters were standardised to just nine piglets per litter. Mortality was significantly lower in dried piglets and those placed under a heat lamp compared to control piglets (Christison et al., 1997). Dewey et al., (2008) compared level of care given to piglets at birth through to 16 days of age. Drying piglets was just one of many additional procedures undertaken on piglets considered to have had maximal care in comparison to standard levels of care. However, maximal care litters did end up heavier at 16 days with no impact on mortality between groups (Dewey et al., 2008). Another study with multiple treatments looked at the impacts of drying piglets with a paper towel, the addition of supplemental heat and two different floor temperatures on growth and thermoregulation (McGinnis et al., 1981). Within this study piglets which were dried had higher rectal temperatures at 1 hour old and higher skin temperatures at 30 minutes and 1 hour of age (McGinnis et al., 1981). The sows in the study had quite small litters of just under 10 piglets per litter, which is not as comparable to modern sows with large litters. As well as paper towels and straw utilised to dry piglets there is research into using drying powders (Goden, 2016; Kiehne, 2006; Pasca et al., 2008). However, the paper by Goden (2016) was not available in English, Kiehne (2006) was too general and Pasca et al. (2008) did not include statistics. The work of Pasca et al. (2008) also showed differences in the thermoregulation pattern when piglets were treated with drying powder, however, this paper did not look at differences in mortality between treatment groups. The development of thermoregulation is key for the piglet to adapt to environmental conditions outside the uterus (Herpin et al., 2002). Another small scale study compared drying piglets straight after birth with no intervention (Pan, 1995). This study again did not look at mortality of growth rates of piglets, they focused on skin and rectal temperatures and there were no treatment effects in this study, however, it should be noted that the 
ambient temperature during the study was particularly high $23-35^{\circ} \mathrm{C}$ compared to recommended temperatures of $18-20^{\circ} \mathrm{C}$ for sow comfort (Pan, 1995). A further study was undertaken by Vasdal et al. (2011) comparing six treatment groups using different methods of drying piglets. Drying piglets and placing piglets at the udder resulted in lower mortality in one but not all batches (Vasdal et al., 2011). They did find however, that litter size; birth weight; latency from birth to suckle; and rectal temperature 2 hours post birth had an impact on mortality independent of treatment (Vasdal et al., 2011). Of the three treatments in the study of Vasdal et al. (2011) which involved drying the piglets, the mortality rate was less than $10 \%$ which was positive considering the sows were loose-housed. In addition, placing the piglets close to the udder (with or without drying) reduces the latency to suckle (Vasdal et al., 2011). Rosvold et al. (2017) looked at overall management effort within 52 herds in Norway, where higher levels of management included drying piglets. Farms which dried piglets as well as supervised farrowing, practiced split suckling as well as other management practices were rewarded with lower levels of piglet mortality (Rosvold et al., 2017) although drying piglets was not an independent treatment. Another study which included drying as part of an overall enhanced management strategy at farrowing showed significant improvements in mortality (White et al., 1996). The extra interventions were estimated to take around 2 minutes of extra processing time with a reasonable amount of time waiting for piglets to be born with at least 15 minutes between piglets (mean 156 minutes per litter in total) (White et al., 1996).

A number of the excluded papers focused on general management around farrowing and its impact on mortality. Ogunbameru et al. (1991) evaluated different configurations of supplementary heat given during farrowing; their study found no benefits of treatment on piglet survival or growth, however, it was not clear what temperature the rooms were during the experiment. One issue which influences piglet performance including mortality is difficult to separate out, this is stockmanship. Self-discipline and a warm nature were positively correlated with good performance on farrowing units in Canada (Ravel et al., 1996).

More evidence is still required to determine which is the best method of drying piglets, particularly that of a peer reviewed nature with robust statistical evaluation to answer the PICO addressed through this report. There is evidence that drying piglets results in less mortality. Although there are a number of methods utilised across the studies of drying piglets which makes direct comparison difficult. There is evidence however, that drying piglets does influence thermoregulation with less of a drop post farrowing in core body temperature. There is also evidence that the temperature of the farrowing room itself has an impact on piglet mortality and sow performance. Drying of piglets would appear to be of value within the general area of farrowing management and as such is not always a standalone treatment. The consideration of creep configuration and type of heating was outside the scope of this knowledge summary. These may have an impact along with the environmental conditions as mentioned above. Farms will vary hugely in terms of creep management and as such this was considered out of the scope of this review.

\section{Methodology Section}

\section{Search}

Databases searched and dates CAB Abstracts on the OVID interface 1973 to 2018 Week 42

covered: PubMed accessed via the NCBI website 1910-October 2018

Search strategy: CAB Abstracts:

1. piglets or exp piglets/ or ((newborn or birth or baby or neonatal or infant) and (pig* or swine))

2. (dry* or warm* or towel* or 'heat lamp')

3. (mortal* or death or surviva* or viabil* or shiver* or chilling or chill or chills or hypothermia or thermoregulation or 'body temperature') or exp mortality/ or exp hypothermia/ or exp thermoregulation/

4. 1 and 2 and 3 


\begin{tabular}{|l|c|c|}
\hline & $\begin{array}{c}\text { PubMed: } \\
1 .\end{array}$ & $\begin{array}{l}\text { piglets OR ((newborn OR birth OR baby OR neonatal OR } \\
\text { infant) and (pig OR pigs OR swine)) }\end{array}$ \\
2. & $\begin{array}{l}\text { drying OR warming OR towel OR towelling OR heat lamp } \\
\text { mortality OR death OR survival OR viability OR shiver OR } \\
\text { shivering OR chilling OR hypothermia OR } \\
\text { thermoregulation OR body temperature } \\
\text { 3. }\end{array}$ \\
\hline Dates searches performed: & $31 / 10 / 2018$ \\
\hline
\end{tabular}

\begin{tabular}{|c|c|}
\hline \multicolumn{2}{|l|}{ Exclusion / Inclusion Criteria } \\
\hline Exclusion: & $\begin{array}{l}\text { - Most common reasons for exclusion was age of pigs, work } \\
\text { focused on sows, embryos or older piglets (not PICO) } \\
\text { - Non-English papers could not be apprised fully as we could } \\
\text { only see the abstract and therefore assessments of methods } \\
\text { and experimental design could not be made } \\
\text { - Papers which we could not get access to were following } \\
\text { extensive online search and following contacting the British } \\
\text { Library (by Clare Boulton RCVS Knowledge) }\end{array}$ \\
\hline Inclusion: & Peer-reviewed articles \\
\hline
\end{tabular}

\begin{tabular}{|l|c|c|c|c|c|}
\hline \multicolumn{5}{|l|}{ Search Outcome } \\
\hline Database & $\begin{array}{c}\text { Number of } \\
\text { results }\end{array}$ & $\begin{array}{c}\text { Excluded - Did } \\
\text { not answer the } \\
\text { PICO }\end{array}$ & $\begin{array}{c}\text { Excluded - Non- } \\
\text { English }\end{array}$ & $\begin{array}{c}\text { Excluded - Could } \\
\text { not get access }\end{array}$ & $\begin{array}{c}\text { Total relevant } \\
\text { papers }\end{array}$ \\
\hline $\begin{array}{l}\text { CAB } \\
\text { Abstracts }\end{array}$ & 262 & 230 & 6 & 7 & 19 \\
\hline PubMed & 35 & 31 & 0 & 0 & 4 \\
\hline Total relevant papers when duplicates removed & & & 8 \\
\hline
\end{tabular}

\section{CONFLICT OF INTEREST}

The author declares no conflicts of interest. 
The author would like to gratefully acknowledge Clare Boulton (RCVS Knowledge) for help with the search strategy and obtaining papers that were not available.

\section{REFERENCES}

1. (2019). Prices \& Stats \Costings \& Herd Performance \Indoor Breeding Herd.

2. Andersen, I. L., Haukvik, I. A., \& Boe, K. E. (2009). Drying and warming immediately after birth may reduce piglet mortality in loose-housed sows. Animal, 3(4), 592-597.

DOI: http://dx.doi.org/10.1017/S1751731108003650

3. Christison, G. I., Wenger, I. I., \& Follensbee, M. E. (1997). Teat seeking success of newborn piglets after drying or warming. Canadian Journal of Animal Science, 77(2), 317-319. DOI:

\section{https://doi.org/10.4141/A96-119}

4. Dewey, C. E., Gomes, T., \& Richardson, K. (2008). Field trial to determine the impact of providing additional care to litters on weaning weight of pigs. Canadian Journal of Veterinary Research, 72(5), 390-395.

5. Goden, B. (2016). How to get more piglets at weaning? Svinovodstvo (Moskva)(8), 22-23.

6. Herpin, P., Damon, M., \& Le Dividich, J. (2002). Development of thermoregulation and neonatal survival in pigs. Livestock Production Science, 78(1), 25-45. DOI: https://doi.org/10.1016/S03016226(02)00183-5

7. Kiehne, R. (2006). Quick dry: warming up by drying piglets off conserving piglet energy. Large animal. Proceedings of the North American Veterinary Conference, Volume 20, Orlando, Florida, USA, 7-11 January, 2006, 329.

8. McGinnis, R. M., Marple, D. N., Ganjam, V. K., Prince, T. J., \& Pritchett, J. F. (1981). The effects of floor temperature, supplemental heat and drying at birth on neonatal swine. Journal of Animal Science, 53(6), 1424-1431. DOI: https://doi.org/10.2527/jas1982.5361424x

9. Ogunbameru, B. O., Kornegay, E. T., \& Wood, C. M. (1991). Evaluation of methods of providing supplemental heat to newborn pigs during and after farrowing. Journal of Animal Science, 69(10), 3939-3944. DOI: https://doi.org/10.2527/1991.69103939x

10. Pan, S. (1995). Effect of mop-drying on body temperature of porcine neonates. Journal of Veterinary and Animal Sciences, 26(1), 62-63.

11. Pasca, I., Pusta, D., Morar, R., Cimpean, A., Sobolu, R., Oroian, R., Dalea, I., \& Bagita, C. (2008). Researches regarding piglet thermoregulation. Lucrari Stiintifice - Zootehnie si Biotehnologii, Universitatea de Stiinte Agricole si Medicina Veterinara a Banatului Timisoara, 41(2), 601-608.

12. Ravel, A., D'Allaire, S., \& Bigras-Poulin, M. (1996). Influence of management, housing and personality of the stockperson on preweaning performances on independent and integrated swine farms in Quebec. Preventive Veterinary Medicine, 29(1), 37-57. DOI: http://dx.doi.org/10.1016/S0167$\underline{5877(96) 01053-7}$ 
13. Rosvold, E. M., Kielland, C., Ocepek, M., Framstad, T., Fredriksen, B., Andersen-Ranberg, I., Naess, G., \& Andersen, I. L. (2017). Management routines influencing piglet survival in loose-housed sow herds. Livestock Science, 196, 1-6. DOI: http://dx.doi.org/10.1016/i.livsci.2016.12.001

14. Vasdal, G., Ostensen, I., Melisova, M., Bozdechova, B., Illmann, G., \& Andersen, I. L. (2011). Management routines at the time of farrowing-effects on teat success and postnatal piglet mortality from loose housed sows. Livestock Science, 136(2/3), 225-231.

DOI: http://dx.doi.org/10.1016/i.livsci.2010.09.012

15. White, K. R., Anderson, D. M., \& Bate, L. A. (1996). Increasing piglet survival through an improved farrowing management protocol. Canadian Journal of Animal Science, 76(4), 491-495.

DOI: https://doi.org/10.4141/cjas96-075 


\section{EVIIDEFeE

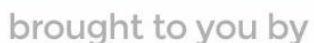 \\ RCVS KNOWLEDGE}

\section{Intellectual Property Rights}

Authors of Knowledge Summaries submitted to RCVS Knowledge for publication will retain copyright in their work, and will be required to grant RCVS Knowledge a non-exclusive license of the rights of copyright in the materials including but not limited to the right to publish, re-

publish, transmit, sell, distribute and otherwise use the materials in all languages and all media throughout the world, and to license or permit others to do so.

\section{Disclaimer}

Knowledge Summaries are a peer-reviewed article type which aims to answer a clinical question based on the best available current evidence. It does not override the responsibility

of the practitioner. Informed decisions should be made by considering such factors as individual clinical expertise and judgement along with patient's circumstances and owners' values. Knowledge Summaries are a resource to help inform and any opinions expressed within the Knowledge Summaries are the author's own and do not necessarily reflect the view of the RCVS Knowledge. Authors are responsible for the accuracy of the content. While the

Editor and Publisher believe that all content herein are in accord with current recommendations and practice at the time of publication, they accept no legal responsibility

for any errors or omissions, and make no warranty, express or implied, with respect to material contained within.

For further information please refer to our Terms of Use.

RCVS Knowledge is the independent charity associated with the Royal College of Veterinary Surgeons (RCVS). Our ambition is to become a global intermediary for evidence based veterinary knowledge by providing access to information

that is of immediate value to practicing veterinary professionals and directly contributes to evidence based clinical decision-making.

https://www.veterinaryevidence.org/

RCVS Knowledge is a registered Charity No. 230886.

Registered as a Company limited by guarantee in England and Wales No. 598443.

Registered Office: Belgravia House, 62-64 Horseferry Road, London SW1P 2AF

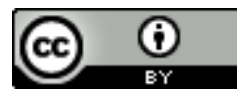

This work is licensed under a Creative Commons Attribution 4.0 International License 